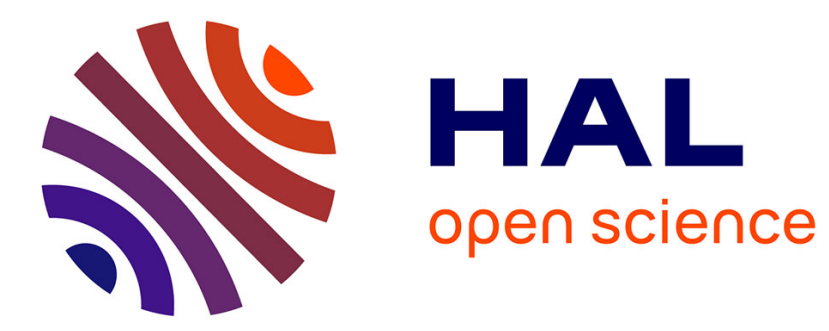

\title{
Driving forces of vertical intra-industry trade in Europe 1996-2005
}

\author{
Lars Jensen, Teit Lüthje
}

\section{To cite this version:}

Lars Jensen, Teit Lüthje. Driving forces of vertical intra-industry trade in Europe 1996-2005. Review of World Economics, 2009, 145 (3), pp.469-488. 10.1007/s10290-009-0022-5 . hal-00535222

\section{HAL Id: hal-00535222 \\ https://hal.science/hal-00535222}

Submitted on 11 Nov 2010

HAL is a multi-disciplinary open access archive for the deposit and dissemination of scientific research documents, whether they are published or not. The documents may come from teaching and research institutions in France or abroad, or from public or private research centers.
L'archive ouverte pluridisciplinaire HAL, est destinée au dépôt et à la diffusion de documents scientifiques de niveau recherche, publiés ou non, émanant des établissements d'enseignement et de recherche français ou étrangers, des laboratoires publics ou privés. 


\title{
Driving forces of vertical intra-industry trade in Europe 1996-2005
}

\author{
Lars Jensen · Teit Lüthje
}

Published online: 11 August 2009

(C) Kiel Institute 2009

\begin{abstract}
A common feature in the empirical literature of intra-industry trade is the analysis of trade between a given reference country and a set of partners. This article differs from previous studies by examining the bilateral trade among all trading partners within a set of partners. Using a panel data approach, we find that differences in factor endowments seem not to be important as a driving force behind vertical intra-industry trade for European countries over the chosen period. More important driving forces are production size, geographical proximity, average income per capita and income distribution overlap.
\end{abstract}

Keywords Vertical intra-industry trade $\cdot$ European trade $\cdot$ Panel data

JEL Classification $\mathrm{F} 10 \cdot \mathrm{F} 14 \cdot \mathrm{F} 15$

\section{Introduction}

Trade between two countries within a product category is characterized as intraindustry trade (IIT) if both export and import exist, and IIT is characterized as horizontal (HIIT) if trade consists of varieties of the same quality, and as vertical (VIIT) if the varieties are of a different quality. Empirical research ${ }^{1}$ points out that VIIT is the dominant type of total IIT.

A common feature of the above mentioned investigations is the analysis of trade between a given reference country and a set of partners. The empirical results are

\footnotetext{
${ }^{1}$ See e.g. Greenaway et al. (1995), Aturupane et al. (1999), Durkin and Krygier (2000), Gullstrand (2002a, b), Mora (2002) and Crespo and Fontoura (2004), Jensen and Lüthje (2008).

L. Jensen · T. Lüthje ( $\bowtie)$

Department of Entrepreneurship and Relationship Management, University of Southern Denmark, Odense, Denmark

e-mail: teit@sam.sdu.dk
} 
not unambiguous with regard to the relationship between differences in factor endowments between trade partners on the one side and the two types of IIT on the other. It is possible that the estimated relationships depend on the reference country. Therefore, it is relevant to examine the bilateral trade among all partners within a set of partners. Such an analysis has not yet been conducted in the international literature. We conduct an econometric analysis of European VIIT in manufactured goods from 1996 to 2005. The countries are the EU-15 countries and four East European countries: Hungary, Slovakia, Poland and the Czech Republic. The choice of countries is determined by two considerations: (1) the availability of data for both trade flows and explanatory variables and (2) the countries should operate on a common market so that problems of trade barriers etc. can be left out of consideration. We also analyze the implications of geographical proximity. This determinant captures such factors as similarities in language and culture and thereby similarity of consumer patterns. Finally, we investigate the role of income distribution overlap between countries and the effect of production size.

In Sect. 2, theoretical foundations and empirical applications are discussed. The measurement of IIT is worked through in Sect. 3, and after some preliminary investigations in Sect. 4, explanatory variables and hypotheses are listed in Sect. 5. The results of the econometric estimations are shown in Sects. 6, and 7 concludes the article.

\section{Theoretical foundations}

In this section, we discuss theoretical foundations of determinants that may explain VIIT. We discuss the effect of income distribution overlap, difference in factor endowment, production size and geographical proximity. By capital endowment we mean physical capital, technological capital as well as human capital. In the analysis, we discuss both the demand side and the production side.

The theoretical framework of VIIT is rooted in the work of Linder (1961) although he did not use the term VIIT explicitly. Linder assumes that the individual demand for quality of a given variety is increasing with income. Considering two countries, an overlap in income distribution determines whether the demand for a given good will exist in both countries. Within this overlap, consumers with low incomes demand low-quality varieties, whereas high-income consumers demand high-quality varieties. However, the overlap in income distribution can be so small that low quality goods demanded in the low-income country are not demanded in the high-income country. The same applies to high-quality goods. Therefore, a variety on a given quality level is not demanded in both countries, and then VIIT in this good cannot exist ${ }^{2}$. Falvey and Kierzkowski (1987), Flam and Helpman (1987), Stokey (1991) and Copeland and Kotwal (1996) also assign a central role to income distributions. Moreover, the level of income per capita is determined by the capital intensity, thus the capital-abundant countries have a relatively high income per

\footnotetext{
${ }^{2}$ Linder (1961), Falvey and Kierzkowski (1987), Stokey (1991), Copeland and Kotwal (1996) and Murphy and Shleifer (1997).
} 
capita, and the labor-abundant countries have a relatively low income per capita. Our first hypothesis is

H1: We expect VIIT to be more prominent among countries with a high degree of income distribution overlap.

Turning to the production side, the quality level of a product variety increases with capital intensity. If a given good is produced in two countries, one of which is capital-abundant and the other is labor-abundant (or less capital-abundant), we may assume that the capital-abundant country produces high-quality varieties, whereas the labor-abundant (or the less capital-abundant) country produces low-quality varieties. Depending on the demand in the two countries, as discussed above, VIIT will arise ${ }^{3}$. Many authors in empirical analysis expect a positive relationship between VIIT and differences in factor endowments, see e.g. Durkin and Krygier (2000), Martín-Montaner and Ríos (2002), Mora (2002), Crespo and Fontoura (2004) and Zhang et al. (2005). However, it is not sufficient to look at the production side; the demand side needs to be included too as discussed above. Since a large difference in factor endowments between two countries also indicates a large difference in income per capita, we may even expect VIIT to be small in case of a too large difference in factor endowments.

When we turn to the empirical evidence of the effect of differences in factor endowments on VIIT, Martín-Montaner and Ríos (2002) and Mora (2002) use the three above mentioned variables as a proxy of capital: physical capital, technological capital and human capital. ${ }^{4}$ Martín-Montaner and Ríos (2002) find a positive relationship between VIIT and the three variables, whereas Mora (2002) finds a negative relationship between VIIT and physical capital. The two other capital variables show a positive relationship, although not significant, as regards human capital. Durkin and Krygier (2000) investigate HIIT and VIIT in relation to physical capital and use as a proxy of the latter, GDP per capita. They find a positive relationship with VIIT. One the one hand, some of the estimated relationships are insignificant, depending on how IIT is separated into HIIT and VIIT. Crespo and Fontoura (2004) also use GDP per capita as a proxy of physical capital and find a positive relationship with VIIT. On the other hand, Gullstrand (2002b), who also uses GDP per capita as a proxy of physical capital, expects a negative relationship with VIIT. However, his empirical results do not support any explanatory power of differences in factor endowments. Finally, it cannot be ruled out that differences in factor endowments at industry level have a different impact on VIIT. Mora (2002: pp 308-310) finds that at industry level for some industries the relationship is positive and for other industries negative with regard to differences in factor endowments. Since we chose VIIT as an aggregated index over industries, the heterogeneity of industries in relation to a trading partner country has implications for the direction of the relationship between the absolute difference in factor endowments and VIIT. In other words the effect of differences in factor

\footnotetext{
3 Falvey (1981), Falvey and Kierzkowski (1987), Flam and Helpman (1987), Stokey (1991), Davis (1995), Copeland and Kotwal (1996) and Murphy and Shleifer (1997).

${ }^{4}$ More precisely, Mora (2002) investigates high-quality VIIT.
} 
endowments is not equal for all countries. Therefore, country-specific effects of differences in factor endowments have to be investigated too. It appears that the empirical results are not unambiguous as regards the relationship between differences in factor endowments and VIIT. This is also confirmed in an analysis by Jensen and Lüthje (2008). Hence we can introduce our second hypothesis

H2: The effect of differences in factor endowments on VIIT depends on trade partners.

The size of an economy matters too. The greater the size of an economy is, the more industries will exist due to economies of scale. In order for VIIT to exist in a given good, both trading partners have to produce the good. A given good will more likely be produced in a large economy than in a small economy due to diversity of industries. Our third hypothesis is

H3: The larger the production size of the trading partners is, the larger VIIT will be.

A pair of countries with very different industry structures and/or demand patterns will necessarily have a lower VIIT than a pair of countries with coincident industry structures and/or demand patterns. Since countries that are close to each other geographically will tend to have relatively similar industry structures and demand patterns due to e.g. linguistic and cultural similarities, VIIT may be larger among such pairs of countries (see also Linder 1961). Furthermore, the information costs increase with geographical distance thereby hampering VIIT. Finally, geographical proximity also reflects transportation costs. The smaller the transportation costs are, the larger is VIIT. In fact, a robust empirical finding is that IIT and accordingly VIIT decline with distance between trading partners (for further details see Venables and Rice 2003). Accordingly, we can formulate our fourth hypothesis

H4: A. The more similar industry structures between the pair of trading countries are, the larger is VIIT.

B. The more similar demand patterns are between the pair of trading countries are, the larger is VIIT.

C. The smaller the information and transportation costs between the pair of trading countries are, the larger is VIIT.

\section{Measurement of intra-industry trade}

IIT between two countries of a product category $j$ is measured by the Grubel and Lloyd (1975) index:

$$
\operatorname{IIT}_{j}=1-\frac{\left|X_{j}-M_{j}\right|}{X_{j}+M_{j}}
$$

where $X_{j}$ and $M_{j}$ are the value of export respectively import inside product category $j,\left|X_{j}-M_{j}\right|$ the net trade, $\left(X_{j}+M_{j}\right)$ is the value of the total trade. Accordingly, the 
part of foreign trade characterized by being inter-industry is $1-\mathrm{IIT}_{j}$. An aggregate index of total IIT between two countries can be attained as a weighted sum of IIT indices:

$$
\mathrm{IIT}=\sum_{j}\left(1-\frac{\left|X_{j}-M_{j}\right|}{X_{j}+M_{j}}\right) \frac{X_{j}+M_{j}}{\sum_{k} X_{k}+M_{k}}=1-\frac{\sum_{j}\left|X_{j}-M_{j}\right|}{\sum_{j} X_{j}+M_{j}}
$$

In order to split the IIT index into a horizontally and a vertically differentiated part Greenaway et al. (1995) reformulate Grubel and Lloyd's index, see Eq. 2, to

$$
\begin{aligned}
\mathrm{IIT} & =\sum_{j \in H}\left(1-\frac{\left|X_{j}-M_{j}\right|}{X_{j}+M_{j}}\right) \frac{X_{j}+M_{j}}{\sum_{k} X_{k}+M_{k}}+\sum_{j \in V}\left(1-\frac{\left|X_{j}-M_{j}\right|}{X_{j}+M_{j}}\right) \frac{X_{j}+M_{j}}{\sum_{k} X_{k}+M_{k}} \\
& =\text { HIIT }+ \text { VIIT }
\end{aligned}
$$

where $H$ refers to horizontally and $V$ to vertically differentiated products, " $j \in p$ " refers to the products that are $p$ differentiated ( $p=H$ or $V$ ).

The products are split into horizontally or vertically differentiated products by the use of unit values as a proxy of quality. IIT is considered to consist of horizontally differentiated products if unit values satisfy the condition

$$
\frac{1}{1+d} \leq \frac{U V_{j}^{x}}{U V_{j}^{m}} \leq 1+d
$$

where $U V_{j}^{x}$ and $U V_{j}^{m}$ are the unit values of imports and exports of product category $j$, and $d$ a chosen dispersion factor. Otherwise, IIT is considered to consist of vertically differentiated products.

Fontagné and Freudenberg (1997) and Greenaway et al. (1995) separate vertically differentiated products from horizontally differentiated products by the use of a dispersion factor of 15 or $25 \%$. In order to evaluate the robustness of the results, Greenaway et al. (1995), Aturupane et al. (1999), Durkin and Krygier (2000), Gullstrand (2002a), Mora (2002) and Crespo and Fontoura (2004) conduct a regression analysis for both dispersion factors and find that the results are not particularly sensitive as regards the chosen dispersion factor. See Nielsen and Lüthje (2002) and Lüthje (2003) for a further discussion of this method.

The index of IIT is calculated from data from OECD's CD-ROM database International Trade by Commodities Statistics HS, 1996-2005 for manufactured goods at a 6-digit product level of the harmonized system (HS) nomenclature (see Table 5 in the Appendix).

\section{Preliminary investigations}

An IIT index measuring intra-industry trade between two countries should remain invariant if it is calculated from trade data reported by a certain country or by data reported from its trade partner due to the symmetry of the formulas. To see whether this is the case, correlations between IIT indices based on trade data reported by a country and data reported by its partner are shown in Table 1. 
Table 1 Correlations of indices based on a report country and partner countries as report country $(d=15 \%)$

\begin{tabular}{|c|c|c|c|c|}
\hline Country & $N$ & $\begin{array}{l}\text { Correlations } \\
\text { of VIIT indices }\end{array}$ & $\begin{array}{l}\text { Correlations } \\
\text { of HIIT indices }\end{array}$ & $\begin{array}{l}\text { Correlations } \\
\text { of IIT indices }\end{array}$ \\
\hline aut & 166 & 0.88 & 0.77 & 0.94 \\
\hline deu & 166 & 0.90 & 0.73 & 0.97 \\
\hline$d n k$ & 166 & 0.91 & 0.57 & 0.94 \\
\hline$e s p$ & 165 & 0.87 & 0.78 & 0.97 \\
\hline fin & 166 & 0.92 & 0.68 & 0.95 \\
\hline fra & 166 & 0.91 & 0.83 & 0.98 \\
\hline$g b r$ & 166 & 0.91 & 0.69 & 0.96 \\
\hline grc & 166 & 0.83 & 0.42 & 0.84 \\
\hline irl & 165 & 0.77 & 0.32 & 0.82 \\
\hline ita & 162 & 0.93 & 0.85 & 0.97 \\
\hline nld & 165 & 0.85 & 0.77 & 0.95 \\
\hline$p r t$ & 166 & 0.89 & 0.74 & 0.95 \\
\hline swe & 167 & 0.93 & 0.72 & 0.97 \\
\hline bel & 119 & 0.90 & 0.77 & 0.95 \\
\hline$c z e$ & 165 & 0.90 & 0.68 & 0.95 \\
\hline hun & 164 & 0.86 & 0.49 & 0.91 \\
\hline pol & 166 & 0.88 & 0.70 & 0.94 \\
\hline$s v k$ & 152 & 0.87 & 0.69 & 0.92 \\
\hline
\end{tabular}

With respect to Ireland, Greece and Hungary, the reported trade data are not in accordance with the figures reported by the partners as regards HIIT. The problem may be caused by erroneously reported trade quantities. These are used to calculate unit values that serve as a basis to separate horizontal trade from vertical. As regards IIT, only trade amounts are used and the two sets of reported indices seem to be reasonably in accordance for all countries. Since correlations of VIIT indices based on report country and partner countries are high, it is reasonable to use an average of the VIIT index of a report country and the partner country as the report country as our measure of VIIT. According to our data, VIIT is the more dominant type of IIT within European trade. Calculating the fraction of VIIT of total IIT, we found an average of $81 \%$.

In Table 2, the average bilateral VIIT from 1996 to 2005 is shown. On the one hand, countries such as Germany, France and Great Britain have a relatively high VIIT with the European countries as a whole. These countries are characterized by being at the same economic and cultural level and by being large economies. The bilateral VIIT between these countries is at a higher level than with other countries. On the other hand, countries such as Greece, Portugal, Finland, Ireland, Poland and Slovakia have a relatively low bilateral VIIT. Furthermore, it appears from Table 2 that geographical proximity matters. Countries far from each other have lower VIIT than countries close to each other. 


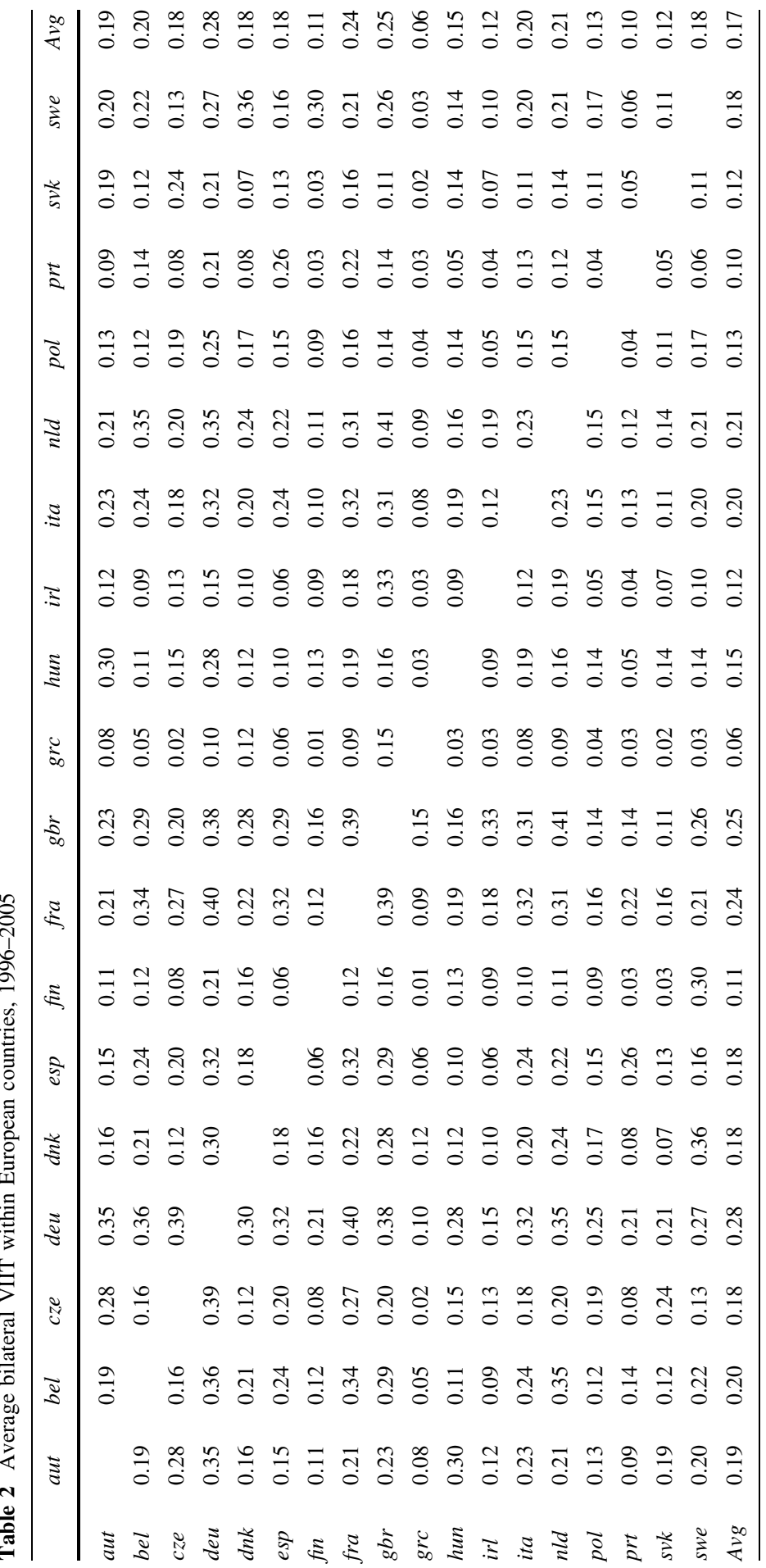




\section{Explanatory variables and hypothesis}

In this section, we operationalize the following explanatory variables: factor endowment, production size, proximity, income distribution overlap and average GDP.

\subsection{Explanatory variables}

\subsubsection{Income distribution overlap}

A measure of the income distribution overlap between two countries is calculated as follows: Let $p_{1}$ denote the proportion of the population in the poorer country that has an income below the $20 \%$ quintile of the income distribution of the richer country. Furthermore, let $p_{2}$ denote the proportion of the population in the richer country that has an income above the $80 \%$ quintile of the income distribution in the poorer country. If the income distribution overlap is small, then both $p_{1}$ and $p_{2}$ will be large. If income distributions are identical, i.e. with full overlap, then both $p_{1}$ and $p_{2}$ will be $20 \%$. As a measure of income distribution overlap, INCO, we calculate

$$
\mathrm{INCO}=1-\frac{\frac{p_{1}+p_{2}}{2}-0.2}{0.7}
$$

The factor 0.7 in the denominator is due to the calculation of $p_{1}$ and $p_{2}$ from income distribution data that are in the form of deciles. Then the maximum of $p_{1}$ and $p_{2}$ is 0.9 . In practice, the minimum value of INCO is 0 indicating virtually no overlap in income distributions. If income distributions are identical, then INCO is 1.

Income distribution data for the European countries are calculated partly from income share data (household disposal income earned within each decile) in World Income Inequality Database (WIID 2C) for a single year (around 1999 for most countries) and partly from GDP per capita data from OECD in 2000 dollars and purchasing power parties (PPP). From the two sources deciles of income distribution can be interpolated. A similar calculation is used by Durkin and Krygier (2000).

\subsubsection{Factor endowment}

As in Martín-Montaner and Ríos (2002) and Mora (2002), we decompose capital into three variables: physical capital, technological capital and human capital.

We measure the endowment of human capital by the fraction of the population, 25-64 years of age that has attained at least upper secondary education. This is a commonly used measure of human capital; see e.g. Barro and Lee (1993), Mora (2002) and Gullstrand (2002a, b). Data is from Eurostat's Internet database for the period from 1996 to 2005. Accordingly, the difference in the endowment of human capital, DHKL, is measured by the absolute difference between the fraction of the population that has attained at least upper secondary education. 
Technological capital, TK, is measured by the cumulated value of R\&D expenditures, see e.g. Coe and Helpman (1995) and Mora (2002), and is calculated by the use of the perpetual inventory method as follows

$$
\mathrm{TK}_{t}=(1-\delta) \mathrm{TK}_{t-1}+\mathrm{RDE}_{t-1}
$$

$\mathrm{TK}_{t}$ is the technological capital for the year $t$, and $\delta$ is the depreciation rate which is assumed to be $15 \% .{ }^{5} \mathrm{RDE}$ is R\&D expenditure estimated in 2000 US\$ and PPP and is based on data from the OECD. The initial technological capital stock, $\mathrm{TK}_{0}$, is calculated as

$$
\mathrm{TK}_{0}=\mathrm{RDE}_{0} /(1+\delta)
$$

where $\mathrm{RDE}_{0}$ is $\mathrm{R} \& \mathrm{D}$ expenditure in the first year, and 1 is the average annual logarithmic growth rate of $R \& D$ expenditures over the analyzed period. The technological capital for each year is divided by the level of employment to obtain the technological capital stock per worker, TKL. Thereby, the difference in the endowment of technological capital can be measured by the absolute difference in technological capital per worker, DTKL.

The physical capital per worker, PKL, is in 2000 US\$ and PPP. As in Leamer (1984) the physical capital is measured by the depreciated sum of cumulated gross domestic investment using the perpetual inventory method. We use data from 1970 to 2007 from the OECD, and the depreciation rate is $7 \%{ }^{6}$ Thereby, the difference in the endowment of physical capital can be measured by the absolute difference in physical capital per worker, DPKL.

\subsubsection{Production size}

The production size of a country is normally measured by the country's GDP, see e.g. Crespo and Fontoura (2004), but, as the focus of the analysis is on the industrial production, GDP is too broad a measure. A more suitable measure of a country's production size in relation to its trading partners seems to be the country's share of the total industrial production of all the analyzed countries, $p$. Accordingly, we measure the production size of a country by the country's share of the total industrial production of the analyzed European countries. We use OECD data for the year 2001.The logarithm of the average share of production between partner countries is denoted ASP.

$$
\mathrm{ASP}=\log \left(\frac{p_{1}+p_{2}}{2}\right)
$$

where $p_{i}$ is country $i$ 's share of production.

\footnotetext{
5 See Coe and Helpman (1995). Alternative measures of technological capital were also calculated assuming $\delta$ to be 5 and 10\% with similar results (Coe and Helpman 1995: pp 883-886). Mora (2002) assumes $15 \%$ too.

${ }^{6}$ See Benhabib and Spiegel (1994). Depreciation rates of 4 and $10 \%$ give very similar results (Benhabib and Spiegel 1994: p 167). Mora (2002) and Crespo and Fontoura (2004) assume 7\% too.
} 


\subsubsection{Geographical proximity}

In a European context, geographical proximity captures similarities in partly language and culture, and thereby similarity of consumer patterns, and partly industry structures. Furthermore, geographical proximity also reflects information and transportation costs. The more similar countries are and the smaller the transportation costs are, the larger is VIIT. We measure geographical proximity by DISTANCE: distance between capitals. ${ }^{7}$

\subsubsection{Average GDP}

In the analysis, we also include the average GDP per capita between two countries, AGDPC, i.e. between country $a$ and country $b$ as

$$
\text { AGDPC }=\left(\frac{\text { GDP }}{\text { CAPITA }} a+\frac{\text { GDP }}{\text { CAPITA }} b\right) / 2
$$

A higher standard of living will lead to a higher demand for differentiated products and thereby a higher VIIT (see Gullstrand 2002a: pp 328-331).

Furthermore, since Gullstrand (2002b) and Crespo and Fontoura (2004) find an interaction between difference in income distribution within countries (measured as difference in GINI coefficients) and difference in GDP per capita, we may suspect the effect of AGDPC to depend on INCO. The sign of the interaction will be determined empirically.

\subsection{Model}

Some of the explanatory variables from the present panel data set are timedependent (DPKL, AGDPC, INCO, DHKL and DTKL) while others are timeinvariant (ASP and DISTANCE). Since VIIT is bounded between 0 and $100 \%$, a linear model will not guarantee expected values between these limits. Consequently, a logistic transformation of VIIT is employed. The data are analyzed by means of (mixed) linear models of the form (see e.g. Frees 2004):

$$
\ln \left(\frac{\mathrm{VIIT}_{i t}}{1-\mathrm{VIIT}_{i t}}\right)=y_{i t}=X_{1 i t} \beta_{1 i}+X_{2 i} \beta_{2}+\alpha_{i}+\varepsilon_{i t}
$$

in which $i$ is an index of country pair and $t$ is an index of time. $X_{1}$ is a row vector of the time dependent variables, and $X_{2}$ is a row vector of the time independent variables (including a constant to capture an intercept). $\alpha_{i}$ captures country pair-specific effects (omitted time-invariant explanatory variables), and $\varepsilon$ is a stochastic residual. The models cannot handle the extreme values 0 and $100 \%$, but such values do not occur in the data set. According to the model, the regression coefficients in $\beta_{1 i}$ may eventually depend on the variable country pair. Hence, the model permits interaction between country pair and the time-dependent explanatory variables.

\footnotetext{
7 In the case of Germany, we use Frankfurt am Main.
} 


\section{Econometric estimations}

A problem with panel data models, as specified in model (5), is the possible correlation between $\alpha$ and the explanatory variables (see e.g. Hausman and Taylor 1981). Treating $\alpha$ as a random variable (a variance component), generalized least squares (GLS), in the case of correlation between $\alpha$ and the explanatory variables, results in biased and inconsistent estimates of regression coefficients (Hausman and Taylor 1981). A possible solution to overcome such a problem is to use so-called "within" estimates of regression coefficients where the $\alpha_{i}$ 's are treated as fixed constants that enter the model in the form of dummy variables. These "within" estimates are unbiased and consistent even in the presence of correlation between $\alpha$ and the explanatory variables. However, by this procedure it is not possible to estimate effects of the time-invariant explanatory variables. Then if the analysis indicates correlation between $\alpha$ and the explanatory variables, a robust estimation procedure has to be sought out. Yet another problem with panel data models of type (5) is the possibility of heteroscedasticity of the residual $\varepsilon$ as well as correlations of some form among country pair residuals. We address this problem by using robust standard errors (White 1980; Liang and Zeger 1986) in the estimation of standard errors. In some of the models, we allow for serial correlation. All the models are estimated by maximum likelihood.

The results of the econometric estimations are shown in Table 3 with a dispersion factor $d=15 \%$, and in Table 4 with a dispersion factor $d=25 \%$. In column (1) in Table 3, a model neglecting the variance component $\alpha$ is estimated by OLS. In case of no correlation between $\alpha$ and the explanatory variables, OLS will result in unbiased and consistent estimates of regression coefficients, although standard errors of the estimates are upward biased and thus not reliable. In case of correlation between $\alpha$ and the explanatory variables, the estimates are biased and inconsistent (Hausman and Taylor 1981). In column (2) "within" estimates are displayed. The large discrepancies between the two sets of estimates indicate a problem with correlation between $\alpha$ and the explanatory variables. In column (3) GLS estimates are shown. A Hausman specification test (Hausman 1978) based on a model (fixed effect and random component) with homoscedacity and no serial correlation has a $\chi^{2}$-value of 15.29 . With 6 degrees of freedom the $p$-value is 0.018 thus indicating a problem with correlation between $\alpha$ and the explanatory variables. Accordingly, the models (1) and (3) can not serve as reference for inference concerning effects of the explanatory variables.

Since model (2) does not permit time-invariant explanatory variables, we estimate an "augmented" regression model (4)

$$
y_{i t}=X_{1 i t} \beta_{1}+X_{2 i} \beta_{2}+v_{i}+\bar{X}_{1 i} \gamma+\varepsilon_{i t}
$$

where $\bar{X}_{1 i}$ is a row vector of averages with respect to time of the time-dependent explanatory variables (Frees 2001, 2004, see also Arellano 1993). One may interpret this model as a model that specifies the dependency of $\alpha$ on the time-dependent variables as $\alpha_{i}=\bar{X}_{1 i} \gamma+v_{i}$. (See also Hsiao 2003). Using GLS estimation in this model results in estimators that are robust to time constant omitted variables bias (Frees 2004). Testing the hypothesis $\gamma=0$ is an alternative to the Hausman 


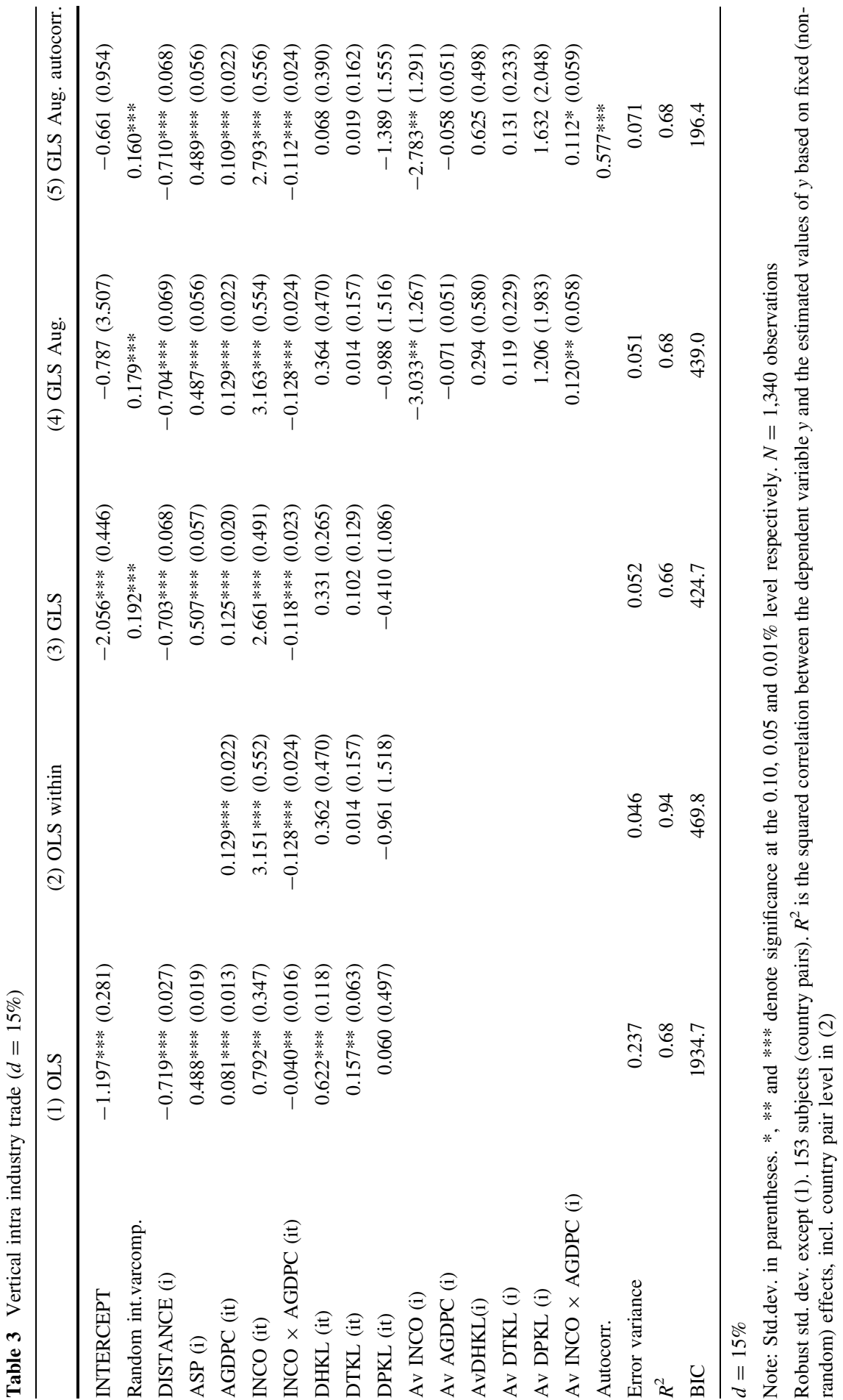




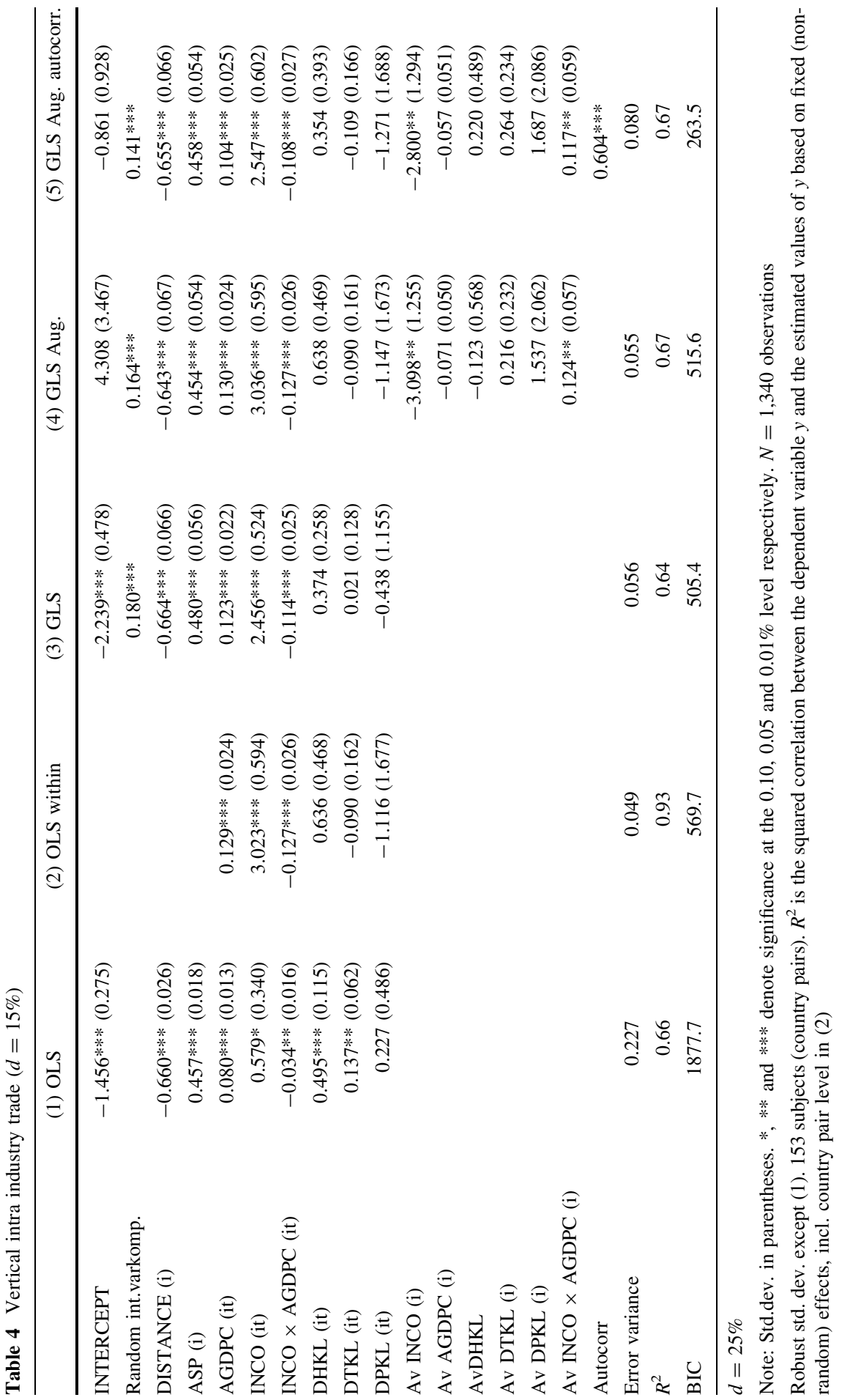


specification test. Furthermore, since we use robust standard errors in the estimation of $\gamma$, this test is more robust to violation of model assumptions (homoscedasticity and no serial correlation). Clearly, from Table 3 the $\gamma$-vector can not be assumed to be the zero vector. We further note that the "within" estimate and the "augmented" estimate of the vector $\beta_{1}$ are equal (Frees 2001, 2004). Some minor discrepancies in Table 3 are due to the estimation routine.

Judged from model (4) in Table 3, DISTANCE has a negative effect on VIIT. Thus hypothesis $\mathrm{H} 4$ is supported by the data. As regards the effect of ASP and INCO on VIIT, the signs of the coefficients are as expected and also significant in these models and thereby offering support for hypothesis $\mathrm{H} 1$ and H3. The effect of AGDPC on VIIT is also significant and positive. On the one hand, AGDPC interacts significantly with our measure of income distribution overlap, INCO. The negative interaction implies that the positive effect on VIIT of a larger income distribution overlap between a country pair levels off when average income of the country pair increases. On the other hand, the positive effect of AGDPC decreases with larger income distribution overlap. In fact, since the regression coefficients for AGDPC and the interaction between INCO and AGDPC are of the same size but of a different sign, a maximum value of INCO (=1) implies no effect of AGDPC. As regards the effects of differences in factor endowments these are positive except the effect of DPKL but not significant. The results of models (2) and (4) indicate that differences in factor endowments have a minor influence on VIIT.

In order to further investigate the effects of differences in factor endowments we set up a model allowing for serial correlation (AR (1)) and variable slopes (random coefficients) as regards DTKL and DPKL. The random slopes can be expressed as $\beta+\delta_{i}$ with $\beta$ as the fixed part and $\delta_{i}$ as a random component with mean zero. Thus $\beta$ is the average slope and $\delta_{i}$ is the difference between the average slope and the slope for country pair $i$. None of the variance components are significant (results not shown). Hence we do not find support for hypothesis H2, i.e. the effect of differences in factor endowments on VIIT does not depend on trade partners. Model (5) takes account of serial correlation and reveals practical identical results as model (4).

In Table 3, some fit-measures are supplied in order to choose the "best" model for inference. $R^{2}$ is a pseudo coefficient of determination, calculated as the squared correlation between the dependent variable $y$ and the estimated values of $y$ based on fixed (non-random) effects. Since the country pair level in model (2) is included, the value of $R^{2}$ is very high but at the expense of many parameters. Without the country pair level the value is 0.026 . This shows that the included time-dependent explanatory variables have only a small effect on VIIT. As a fit measure that also takes into account the number of parameters of the fitted model is Baysian information criterion (BIC), calculated as

$$
\mathrm{BIC}=-2 \cdot \log \text { likelihood }+ \text { number of parameters } \cdot \log \left(\mathrm{N}^{*}\right)
$$

where $\mathrm{N}^{*}$ is the number of subjects or country pairs $(=153)$. A smaller value indicates a better and more parsimonious model. In this sense, model (5) in Table 3 is the best model among the relevant models (2), (4) and (5) indicating that inference concerning effects should be performed in model (5). 
In order to investigate the robustness of the conclusions to different choices of dispersion factor, results for $d=25 \%$ are shown in Table 4. The conclusions regarding the effect of the explanatory variables are the same as with $d=15 \%$.

\section{Conclusions}

Using panel data methods, we conducted an econometric analysis of intra-industry trade with vertically differentiated products among the EU-15 countries and four East European countries: Hungary, Slovakia, Poland and the Czech Republic. We investigated the effect of differences in factor endowments and other determinants that emerge from theory: income distribution overlap, average income, share of the total industrial production and geographical proximity.

We find that differences in factor endowments seem not to be important as a driving force behind VIIT for European countries in the period 1996-2005. More important driving forces are production size, geographical proximity, average income per capita and income distribution overlap. Countries characterized by being on a high economic level and by being large economies have a higher bilateral VIIT with each other than with other countries. Furthermore, countries with large income distribution overlap tend to have a large VIIT. Finally, countries far from each other have lower VIIT than countries close to each other.

Acknowledgments We acknowledge helpful suggestions and comments by the anonymous reviewer.

\section{Appendix}

See Tables 5 and 6.

Table 5 Manufactured goods at a 2-digit product level

28 Inorgn chem; compds of prec met, radioact elements etc

29 Organic chemicals

30 Pharmaceutical products

31 Fertilizers

32 Tanning/dyeing extract; tannins and derivs; pigm etc

33 Essential oils and resinoids; perf, cosmetic/toilet prep

34 Soap, organic surface-active agents, washing prep, etc

35 Albuminoidal subs; modified starches; glues; enzymes 36 Explosives; pyrotechnic prod; matches; pyrop alloy; etc

37 Photographic or cinematographic goods
63 Other made up textile articles; sets; worn clothing etc

64 Footwear, gaiters and the like; parts of such articles

65 Headgear and parts thereof

66 Umbrellas, walking-sticks, seatsticks, whips, etc

67 Prepr feathers and down; arti flower; articles human hair

68 Art of stone, plaster, cement, asbestos, mica/sim mat

69 Ceramic products

70 Glass and glassware

71 Natural/cultured pearls, prec stones and metals, coin etc

72 Iron and steel 
Table 5 continued

38 Miscellaneous chemical products

39 Plastics and articles thereof

40 Rubber and articles thereof

41 Raw hides and skins (other than furskins) and leather

42 Articles of leather; saddlery/harness; travel goods etc

43 Furskins and artificial fur; manufactures thereof 44 Wood and articles of wood; wood charcoal

45 Cork and articles of cork

46 Manufactures of straw, esparto/other plaiting mat; etc

47 Pulp of wood/of other fibrous cellulosic mat; waste etc

48 Paper and paperboard; art of paper pulp, paper/ paperboard

49 Printed books, newspapers, pictures and other product etc

50 Silk

51 Wool, fine/coarse animal hair, horsehair yarn and fabric

\section{Cotton}

53 Other vegetable textile fibres; paper yarn and woven fab

54 Man-made filaments

55 Man-made staple fibres

56 Wadding, felt and nonwoven; yarns; twine, cordage, etc

57 Carpets and other textile floor coverings

58 Special woven fab; tufted tex fab; lace; tapestries etc

59 Impregnated, coated, cover/laminated textile fabric etc

60 Knitted or crocheted fabrics

61 Art of apparel and clothing access, knitted or crocheted.

62 Art of apparel and clothing access, not knitted/ crocheted
73 Articles of iron or steel

74 Copper and articles thereof

75 Nickel and articles thereof

76 Aluminium and articles thereof

78 Lead and articles thereof

79 Zinc and articles thereof

80 Tin and articles thereof

81 Other base metals; cermets; articles thereof

82 Tool, implement, cutlery, spoon and fork, of base met etc

83 Miscellaneous articles of base metal

84 Nuclear reactors, boilers, mchy and mech appliance; parts

85 Electrical mchy equip parts thereof; sound recorder etc

86 Railw/tramw locom, rolling-stock and parts thereof; etc

87 Vehicles o/t railw/tramw roll-stock, pts and accessories

88 Aircraft, spacecraft, and parts thereof.

89 Ships, boats and floating structures

90 Optical, photo, cine, meas, checking, precision, etc

91 Clocks and watches and parts thereof

92 Musical instruments; parts and access of such articles

93 Arms and ammunition; parts and accessories thereof

94 Furniture; bedding, mattress, matt support, cushion etc

95 Toys, games and sports requisites; parts and access thereof

96 Miscellaneous manufactured articles 


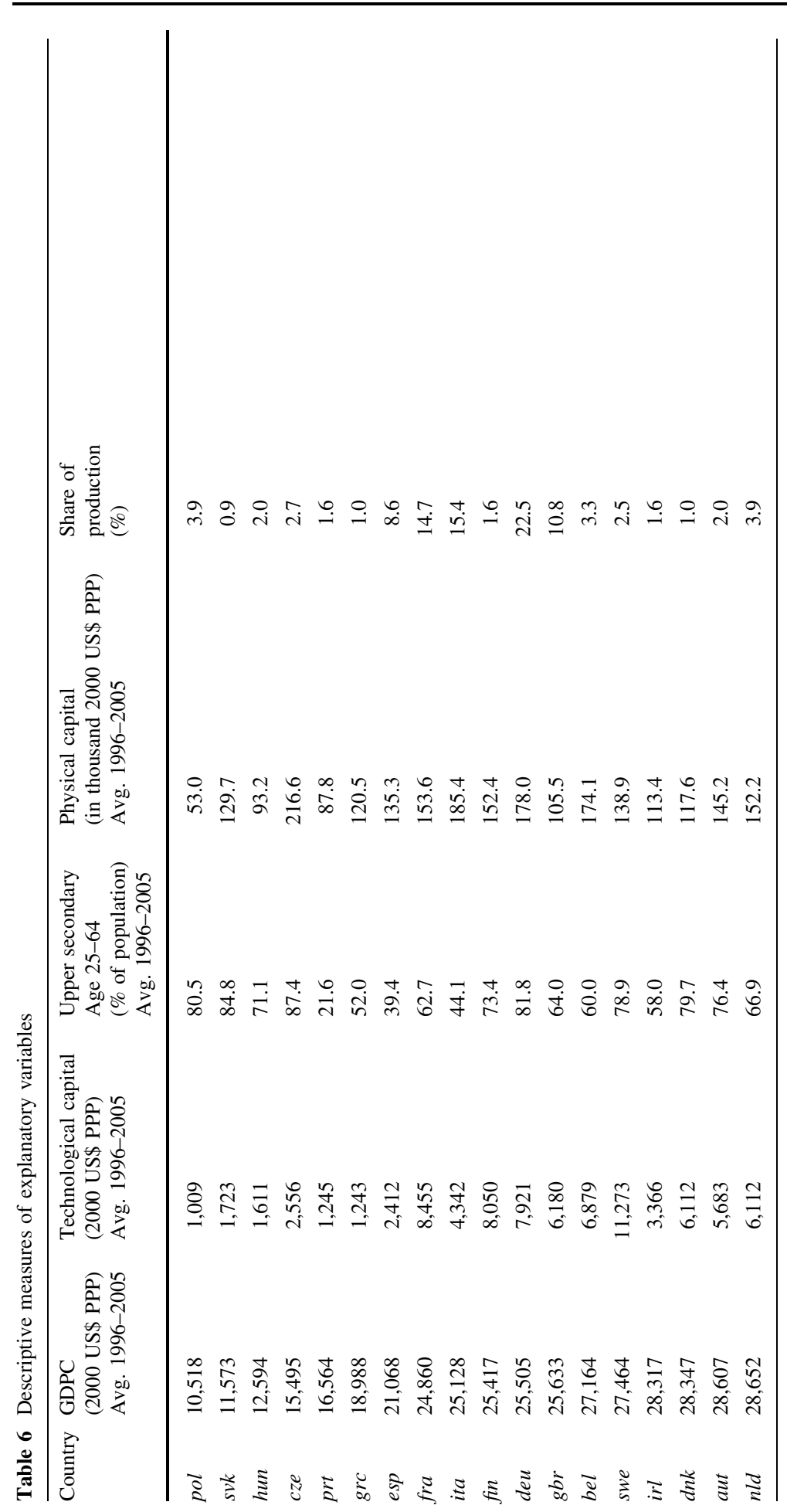




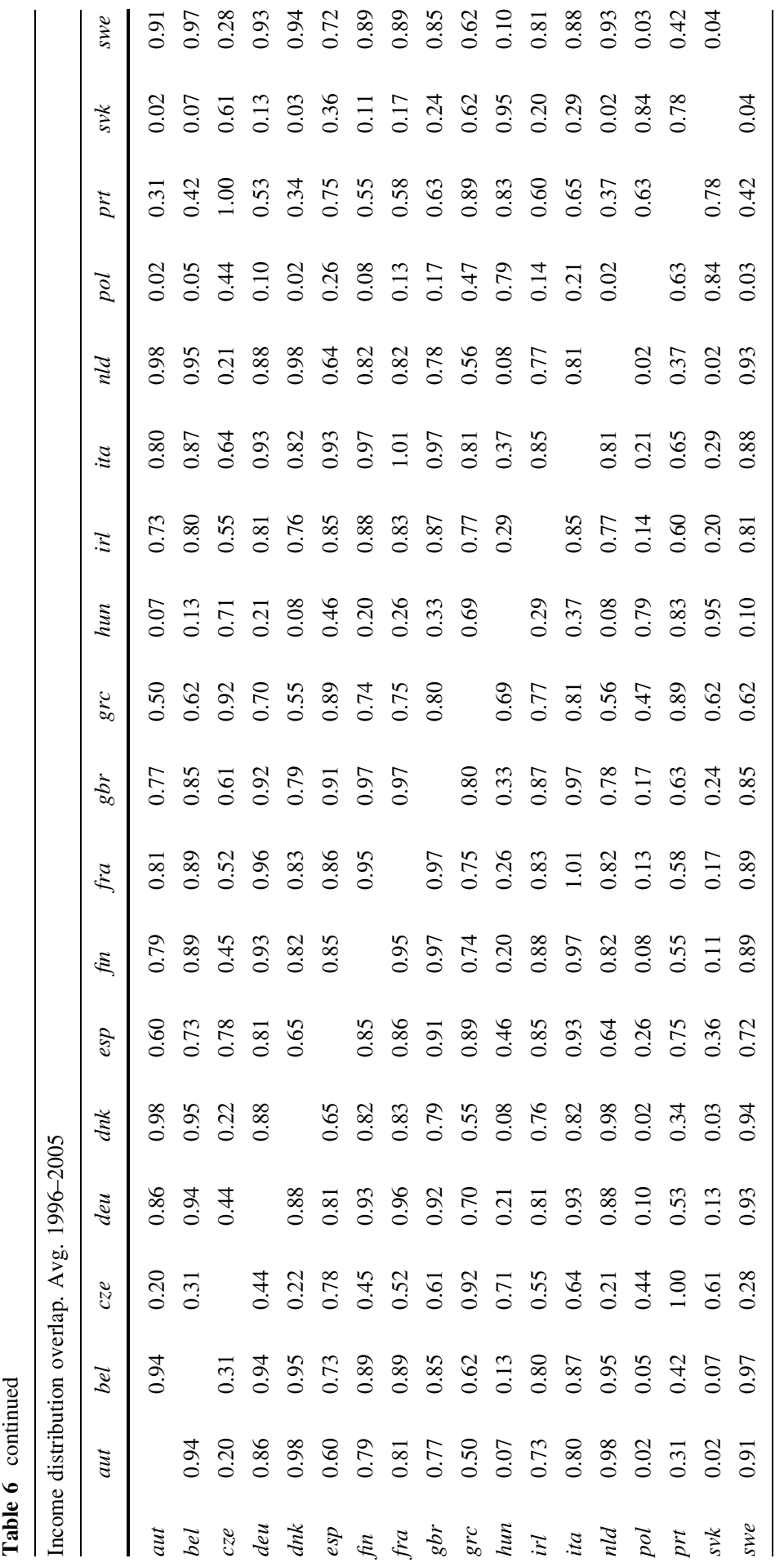




\section{References}

Arellano, M. (1993). On the testing of correlated effects with panel data. Journal of Econometrics, 59(1/ 2), 87-97.

Aturupane, C., Djankov, S., \& Hoekman, B. (1999). Horizontal and vertical intra-industry trade between Eastern Europe and the European Union. Weltwirtschaftliches Archiv/Review of World Economics, $135(1), 62-81$.

Barro, R., \& Lee, J. W. (1993). International comparisons of educational attainment. Journal of Monetary Economics, 32(2), 363-394.

Benhabib, J., \& Spiegel, M. (1994). The role of human capital in economic development: Evidence from aggregate cross-country data. Journal of Monetary Economics, 34(2), 143-173.

Coe, D. T., \& Helpman, E. (1995). International R\&D spillovers. European Economic Review, 39(5), $859-887$.

Copeland, B. R., \& Kotwal, A. (1996). Product quality and the theory of comparative advantage. European Economic Review, 40(9), 1745-1760.

Crespo, N., \& Fontoura, M. P. (2004). Intra-industry trade by types: What can we learn from Portuguese data? Review of World Economics/Weltwirtschaftliches Archiv, 140(1), 52-79.

Davis, D. R. (1995). Intra-industry trade: A Heckscher-Ohlin-Ricardo approach. Journal of International Economics, 39(3), 201-226.

Durkin, J. T., \& Krygier, M. (2000). Differences in GDP per capita and the share of intra-industry trade: The role of vertically differentiated trade. Review of International Economics, 8(4), 760-774.

Falvey, R. E. (1981). Commercial policy and intra-industry trade. Journal of International Economics, 11(4), 495-511.

Falvey, R. E., \& Kierzkowski, H. (1987). Product quality, intra-industry trade and (Im)perfect competition. From In H. Kierzkowski (Ed.), Protection and competition in international trade. Oxford: Basil Blackwell.

Flam, H., \& Helpman, E. (1987). Vertical product differentiation and North-South trade. American Economic Review, 77(5), 810-822.

Fontagné, L., \& Freudenberg, M. (1997). Intra-Industry Trade: Methodological Issues Reconsidered. (CEPII Working Paper No. 97-01). Paris: Centre D’Etudes Prospectives et d'Informations Internationales.

Frees, E. W. (2001). Omitted variables in Longitudinal Data Models. Canadian Journal of Statistics, 29(4), 573-595.

Frees, E. W. (2004). Longitudinal and panel data: analysis and applications in the social sciences. Cambridge: Cambridge University Press.

Greenaway, D., Hine, R., \& Milner, C. (1995). Vertical and horizontal intra-industry trade: A cross industry analysis for the United Kingdom. Economic Journal, 105(433), 1505-1518.

Grubel, H. G., \& Lloyd, P. J. (1975). Intra-industry trade: The theory and measurement of international trade in differentiated products. London: MacMillan Press.

Gullstrand, J. (2002a). Does the measurement of intra-industry trade matter? Weltwirtschaftliches Archiv/ Review of World Economics, 138(2), 317-339.

Gullstrand, J. (2002b). Demand patterns and vertical intra-industry trade with special reference to to North-South Trade. Journal of International Trade and Development, 11(4), 429-455.

Hausman, J. A. (1978). Specification tests in econometrics. Econometrica, 46(4), 1251-1271.

Hausman, J. A., \& Taylor, W. E. (1981). Panel data and unobservable individual effects. Econometrica, 49(6), 1377-1398.

Hsiao, C. (2003). Analysis of panel data. Cambridge: Cambridge University Press.

Jensen, L., \& Lüthje, T. (2008). Country specific effects of differences in factor endowments on intraindustry trade-illustrated by the Danish case. Global Business and Finance Review, 13(1), 35-46.

Leamer, E. (1984). Sources of comparative advantage. Cambridge, MA: MIT Press.

Liang, K., \& Zeger, S. L. (1986). Longitudinal data analysis using generalized linear models. Biometrika, 73(1), 13-22.

Linder, S. B. (1961). An essay on trade and transformation. Stockholm: Almqvist \& Wiksell.

Lüthje, T. (2003). Is intra-industry trade in reality two-way trade? Global Business and Finance Review, $8(1), 89-102$.

Martín-Montaner, J. A., \& Ríos, V. O. (2002). Vertical specialization and intra-industry trade: The role of factor endowments. Weltwirtschaftliches Archiv/Review of World Economics, 138(2), 340-365. 
Mora, C. D. (2002). The role of comparative advantage in trade within industries: A panel data approach for the European Union. Weltwirtschaftliches Archiv/Review of World Economics, 138(2), 291-316.

Murphy, K. M., \& Shleifer, A. (1997). Quality and trade. Journal of Development Economics, 53, 1-15.

Nielsen, J. U.-M., \& Lüthje, T. (2002). Tests of the empirical classification of horizontal and vertical intra-industry trade. Weltwirtschaftliches Archiv/Review of World Economics, 138(4), 587-604.

Stokey, N. L. (1991). The volume and composition of trade between rich and poor countries. Review of Economic Studies, 58(1), 63-80.

Venables, A. J., Rice, P. G., \& Stewart M. (2003). Topics in Economic Analysis and Policy, 3(1):1-23.

White, H. (1980). A hetroskedastictity-consistent covariance matrix estimator and a direct test for hetroskedasticity. Econometrica, 48(4), 817-838.

Zhang, J., van Witteloostuijn, A., \& Zhou, C. (2005). Chinese bilateral intra-industry trade: A panel data study for 50 countries in the 1992-2001 period. Weltwirtschaftliches Archiv/Review of World Economics, 141(3), 510-540. 